\title{
Women and the U.S. Mass Media: The Majority/Minority
}

Clarence W. Thomas*

Mass Communications, The Robertson School of Media and Culture, USA

"Corresponding author: Clarence W. Thomas, Mass Communications, The Robertson School of Media and Culture, USA, Tel: 804-827-3772; E-mail: cwthomas@vcu.edu

Rec date: Mar 01, 2014, Acc date: Jul 28, 2014, Pub date: Aug 05, 2014

Copyright: (C) 2014 Thomas CW. This is an open-access article distributed under the terms of the Creative Commons Attribution License, which permits unrestricted use, distribution, and reproduction in any medium, provided the original author and source are credited.

\section{Commentary}

In the United States (and the world for that matter), the proportion of men to women is approximately 1 to 1 . However, despite the fact that there are as many women as men, women have traditionally and historically been treated as second class citizens. Women have suffered many, if not more, of the disadvantages (bias, prejudice, stereotyping, etc.) usually associated with being a minority-Black, Hispanic, Asian in the United States. To add insult to injury, the historical portrayal and presence of women in the U.S. mass media (entertainment, advertising, etc.) has not been very good at all.

In terms of portrayal, women are often presented as less intelligent and subservient to men. They are also presented as sex objects who only exist to please men. To make matters worse, the self- esteem, self worth and body image of women is often assaulted by un-realistic media portrayal which many girls and women feel they must emulate. Girls and women in the media are often depicted with body types which most "real" women do not have. In some cases, girls and women are presented with body types, via the media, which do not exist in nature. Therefore, it is no surprise that most women (over 95\%), when polled, do not see themselves as beautiful.

In terms of presence, women are greatly underrepresented in the media( behind the scenes) workforce-which tends to be dominated by white males. Along these lines, a recent UCLA Hollywood Diversity Report paints a dismal picture. For example, women are outnumbered by men in lead roles in film by 2 to 1 . In addition, less than $10 \%$ of Oscar winning films were directed by women. It is also noted that less than $20 \%$ of Oscar winning films featured female leads. This theme continues with writing when we consider that only about $14 \%$ of the writers of major films have been women.

In essence, as America becomes increasingly diverse, the media does not seem to be keeping up. The time has come and is now overdue for the media (entertainment, advertising, news, etc.) to at least keep pace with society in terms of representation women and minority groups. Perhaps, the media might even lead society one day. 